Littel, R. J.; Versteeg, G. F.; van Swaaij, W. P. M. On the kinetics of $C O S$ with primary and secondary amines in aqueous solutions. $A I C h E J .1992 c$, in press.

Philipp, B.; Dautzenberg, H. Kinetische Untersuchungen zur Bildung und Zersetzung von Monothiocarbonat in wässrige Lösung. Z. Phys. Chem. 1965, 229, 210-224.

Reilly, J. T.; Schubert, C. N.; Lindner, J. R.; Donohue, M. D.; Kelly, R. M. Effect of heterocyclic amine additives on the absorption rates of carbonyl sulfide and carbon dioxide in aqueous methyldiethanolamine solutions. Chem. Eng. Commun. 1990, 93, 181-191.

Sharma, M. M. Kinetics of reactions of carbonyl sulphide and carbon dioxide with amines and catalysis by Bronsted bases of the hydrolysis of COS. Trans. Faraday Soc. 1965, 61, 681-688.

Thompson, H. W.; Kearton, C. F.; Lamb, S. A. The kinetics of the reaction between carbonyl sulphide and water. J. Chem. Soc. $1935,1033-1037$.
Tomcej, R. A.; Otto, F. D. Absorption of $\mathrm{CO}_{2}$ and $\mathrm{N}_{2} \mathrm{O}$ into aqueous solutions of methyldiethanolamine. AIChE J. 1989, 35, 861-864.

Versteeg, G. F.; van Swaaij, W. P. M. On the kinetics between $\mathrm{CO}_{2}$ and alkanolamines both in aqueous and non-aqueous solutionsII: Tertiary amines. Chem. Eng. Sci. 1988a, 43, 587-591.

Versteeg, G. F.; van Swaaij, W. P. M. Solubility and diffusivity data of acid gases $\left(\mathrm{CO}_{2}, \mathrm{~N}_{2} \mathrm{O}\right)$ in aqueous alkanolamine solutions. J. Chem. Eng. Data 1988b, 33, 29-34.

Westerterp, K. R.; van Swaaij, W. P. M.; Beenackers, A. A. C. M. Chemical Reactor Design and Operation; Wiley: New York, 1984.

Yu, W.-C.; Astarita, G.; Savage, D. W. Kinetics of carbon dioxide absorption in solutions of methyldiethanolamine. Chem. Eng. Sci. $1985,40,1585-1590$

Received for review July 25, 1991

Revised manuscript received January 30, 1992 Accepted February 5, 1992

\title{
Kinetic Study of COS with Tertiary Alkanolamine Solutions. 2. Modeling and Experiments in a Stirred Cell Reactor
}

\author{
Rob J. Littel,* Geert F. Versteeg, and Wim P. M. van Swaaij \\ Department of Chemical Engineering, University of Twente, P.O. Box 217, \\ 7500 AE Enschede, The Netherlands
}

\begin{abstract}
Absorption experiments of COS into aqueous solutions of MDEA and DEMEA at $303 \mathrm{~K}$ have been carried out in a stirred cell reactor. An absorption model, based on Higbie's penetration theory, has been developed and applied to interpret the absorption experiments, using the kinetic data obtained in part 1 of the present work. Experimental and calculated absorption rates agreed reasonably well at relatively low amine concentrations but deviated increasingly with increasing amine concentration. These deviations must very probably be attributed to an underestimation, by the $\mathrm{COS}-\mathrm{N}_{2} \mathrm{O}$ analogy, of the COS solubility in rather concentrated amine solutions. The absorption model has been applied to investigate the discrepancies between the present work and kinetic data for MDEA reported in the open literature. It has been shown that these discrepancies were possibly due to small amounts of rapidly reacting contaminants.
\end{abstract}

\section{Introduction}

In part 1 (Littel et al., 1992b) kinetic data have been presented for the reaction of COS with aqueous solutions of triethanolamine (TEA), methyldiethanolamine (MDEA), dimethylmonoethanolamine (DMMEA), and diethylmonoethanolamine (DEMEA) at various temperatures. These kinetic experiments were carried out in an intensely stirred batch reactor. On the basis of experiments in aqueous and nonaqueous solutions, a reaction mechanism for the reaction of COS with tertiary amines has been proposed which can be regarded as the basecatalyzed analogue of the reaction mechanism proposed by Philipp and Dautzenberg (1965) for the COS hydrolysis. The observed overall reaction rates were about a factor of 30 lower than those reported by Al-Ghawas et al. (1989) for the absorption of COS into aqueous MDEA solutions in a wetted sphere absorber.

In this article experimental data are presented for the absorption of COS into aqueous solutions of MDEA and DEMEA which were obtained by means of the stirred cell technique. The amine concentrations applied in these absorption experiments were substantially higher than those used in part 1. An absorption model, based on Higbie's penetration theory, was developed to interpret the absorption experiments, using the kinetic data obtained

* Author to whom correspondence should be addressed. Present address: Koninklijke/Shell Laboratorium Amsterdam, P.O. Box 3003, 1003 AA Amsterdam, The Netherlands. in part 1 (Littel et al., 1992b). The absorption model was also applied to investigate the discrepancies between the present work and the kinetic data reported by Al-Ghawas et al. (1989).

\section{Experimental Section}

The kinetic experiments for MDEA and DEMEA were carried out in a stirred cell reactor. The experimental setup and procedure have been described in detail elsewhere (see, e.g., Blauwhoff et al., 1984).

For the interpretation of the kinetic experiments solubility and diffusivity data are required which generally cannot be measured in a direct way in a reactive system. The solubility data were estimated by means of a COS$\mathrm{N}_{2} \mathrm{O}$ analogy (Littel et al., 1992a). This analogy appears to be valid only for relatively diluted aqueous solutions (Littel et al., 1992a, 1992c), which might result in an underestimation of the COS solubility for the amine solutions applied in the present work. Solubility data for $\mathrm{N}_{2} \mathrm{O}$ in aqueous MDEA and DEMEA solutions were reported by Versteeg and van Swaaij (1988b) and Littel et al. (1992a), respectively. The diffusivity of $\mathrm{COS}$ in amine solutions was calculated from the COS diffusivity in water with the help of the modified Stokes-Einstein relationship developed by Versteeg and van Swaaij (1988b). The COS diffusivity in water at $303 \mathrm{~K}$ was estimated from the COS diffusivity at $298 \mathrm{~K}$ (Littel et al., 1992a), assuming the same activation energy as reported by Versteeg and van Swaaij (1988b) for the diffusivity of $\mathrm{CO}_{2}$ in water. 
MDEA and DEMEA were obtained from Janssen Chimica (purity 99+\%) and were used as received. Chemical analysis of the pure tertiary amines showed that the remaining $1 \%$ impurities consisted primarily of water. COS with a minimum purity of $97.5 \%$ was obtained from UCAR.

\section{Modeling}

In order to interpret the kinetic experiments an absorption model has been developed, based on Higbie's penetration theory.

The reaction scheme which has been incorporated in this flux model is given by reactions $1-4$. The finite rate

$$
\begin{gathered}
\mathrm{COS}+\mathrm{H}_{2} \mathrm{O}+\mathrm{R}_{3} \mathrm{~N} \rightleftharpoons \mathrm{HCO}_{2} \mathrm{~S}^{-}+\mathrm{R}_{3} \mathrm{NH}^{+} \\
\mathrm{HCO}_{2} \mathrm{~S}^{-}+\mathrm{H}_{2} \mathrm{O}+\mathrm{R}_{3} \mathrm{~N} \rightleftarrows \mathrm{HS}^{-}+\mathrm{HCO}_{3}^{-}+\mathrm{R}_{3} \mathrm{NH}^{+} \\
\mathrm{HCO}_{3}^{-}+\mathrm{OH}^{-}=\mathrm{CO}_{3}{ }^{2-}+\mathrm{H}_{2} \mathrm{O} \\
\mathrm{R}_{3} \mathrm{NH}^{+}+\mathrm{OH}^{-}=\mathrm{R}_{3} \mathrm{~N}+\mathrm{H}_{2} \mathrm{O}
\end{gathered}
$$

reactions 1 and 2 represent the reaction mechanism proposed in part 1 (Littel et al., 1992b) for the reaction between COS and a tertiary amine in aqueous solutions. Reactions 3 and 4 are equilibrium reactions and are assumed to be instantaneous with respect to mass transfer. Considering the very low overall reaction rates (Philipp and Dautzenberg, 1965), the direct reaction between COS and $\mathrm{OH}^{-}$was not taken into account.

For each component $i$ the following mass balance applies:

$$
\frac{\partial C_{i}(x, t)}{\partial t}=D_{i} \frac{\partial^{2} C_{i}(x, t)}{\partial x^{2}}+R_{i}(x, t)
$$

with initial and boundary conditions:

$$
\begin{array}{rlrl}
t & =0, x>0: & C_{i}(x, t=0) & =C_{i, \text { bulk }} \\
t>0, x & =\infty: & C_{i}(x=\infty, t) & =C_{i, \text { bulk }} \\
t>0, x & =0:-D_{i}\left(\frac{\partial C_{i}(x, t)}{\partial x}\right)_{x=0}=k_{\mathrm{g}, i}\left(C_{\mathrm{g}, i}-\frac{C_{i}(x=0, t)}{m_{i}}\right)
\end{array}
$$

For the nonvolatile components the right-hand side of boundary condition 8 is equal to zero. The values for $C_{i, \text { bulk }}$ in eqs 6 and 7 follow from the assumption of equilibrium conditions in the liquid bulk. Equilibria, which were taken into account for the calculation of the equilibrium compositions in the liquid bulk, are summarized in Table $\mathrm{I}$. The production terms figuring in eq 5 are specified for each component in Table II.

The set of nonlinear coupled partial differential equations 5-8 was solved numerically by means of a discretization technique. Extensive information concerning the numerical treatment can be obtained elsewhere (Cornelisse et al., 1980; Versteeg et al., 1989; Littel et al., 1991).

Solving eqs 5-8 yields concentration profiles for each component. Also the contact time averaged COS absorption flux can be calculated and this calculated absorption flux can be compared to the experimentally measured absorption flux.

\section{Results and Discussion}

4.1. Aqueous Solutions of MDEA and DEMEA at $303 \mathrm{~K}$. Absorption experiments of COS into aqueous solutions of MDEA and DEMEA have been carried out at $303 \mathrm{~K}$ in a stirred cell reactor. The experimental conditions and measured enhancement factors are summarized
Table I. Equilibria Used in Bulk Composition Calculations

$$
\begin{array}{lr}
\mathrm{COS}+\mathrm{OH}^{-}=\mathrm{HCO}_{2} \mathrm{~S}^{-} & K_{\mathrm{COS} 1}=\frac{\left[\mathrm{HCO}_{2} \mathrm{~S}^{-}\right]}{\left[\mathrm{OH}^{-}\right][\mathrm{COS}]} \\
\mathrm{HCO}_{2} \mathrm{~S}^{-}+\mathrm{OH}^{-}=\mathrm{HCO}_{3}^{-}+\mathrm{HS}^{-} & K_{\mathrm{COS} 2}=\frac{\left[\mathrm{HCO}_{3}^{-}\right]\left[\mathrm{HS}^{-}\right]}{\left[\mathrm{HCO}_{2} \mathrm{~S}^{-}\right]\left[\mathrm{OH}^{-}\right]} \\
\mathrm{H}_{2} \mathrm{~S}+\mathrm{H}_{2} \mathrm{O}=\mathrm{HS}^{-}+\mathrm{H}_{3} \mathrm{O}^{+} & K_{\mathrm{H}_{2} \mathrm{~S}}=\frac{\left[\mathrm{HS}^{-}\right]\left[\mathrm{H}_{3} \mathrm{O}^{+}\right]}{\left[\mathrm{H}_{2} \mathrm{~S}_{[2} \mathrm{H}_{2} \mathrm{O}\right]} \\
\mathrm{HS}^{-}+\mathrm{H}_{2} \mathrm{O}=\mathrm{S}^{2-}+\mathrm{H}_{3} \mathrm{O}^{+} & K_{\mathrm{HS}}=\frac{\left[\mathrm{S}^{2-}\right]\left[\mathrm{H}_{3} \mathrm{O}^{+}\right]}{\left[\mathrm{HS}^{-}\right]\left[\mathrm{H}_{2} \mathrm{O}\right]} \\
\mathrm{CO}_{2}+\mathrm{OH}^{-}=\mathrm{HCO}_{3}^{-} & K_{\mathrm{C} 1}=\frac{\left[\mathrm{HCO}_{3}^{-}\right]}{\left[\mathrm{CO}_{2}\right]\left[\mathrm{OH}^{-}\right]} \\
2 \mathrm{H}_{2} \mathrm{O}=\mathrm{H}_{3} \mathrm{O}^{+}+\mathrm{OH}^{-} & K_{\mathrm{H}_{2} \mathrm{O}}=\frac{\left[\mathrm{H}_{3} \mathrm{O}^{+}\right]\left[\mathrm{OH}^{-}\right]}{\left[\mathrm{H}_{2} \mathrm{O}^{2}\right.} \\
\mathrm{RCO}_{3} \mathrm{NH}^{-}+\mathrm{H}_{2} \mathrm{O}=\mathrm{R}_{3} \mathrm{~N}+\mathrm{H}_{3} \mathrm{O}^{+} & K_{\mathrm{A} 1}=\frac{\left[\mathrm{R}_{3} \mathrm{~N}^{-}\right]\left[\mathrm{H}_{3} \mathrm{O}^{+}\right]}{\left[\mathrm{R}_{3} \mathrm{NH}^{+}\right]\left[\mathrm{H}_{2} \mathrm{O}\right]}
\end{array}
$$

Table II. Production Terms

$$
\begin{aligned}
& \text { COS } \quad R_{\mathrm{COS}}=k_{1,2}\left[\mathrm{HCO}_{2} \mathrm{~S}^{-}\right]\left[\mathrm{R}_{3} \mathrm{NH}^{+}\right]-k_{1,1}[\mathrm{COS}]\left[\mathrm{R}_{3} \mathrm{~N}\right] \\
& \mathrm{R}_{3} \mathrm{~N} \quad R_{\mathrm{R}_{3} \mathrm{~N}}=k_{1,2}\left[\mathrm{HCO}_{2} \mathrm{~S}^{-}\right]\left[\mathrm{R}_{3} \mathrm{NH}^{+}\right]-k_{1,1}[\mathrm{COS}]\left[\mathrm{R}_{3} \mathrm{~N}\right]+ \\
& k_{2,2}\left[\mathrm{R}_{3} \mathrm{NH}^{+}\right]\left[\mathrm{HS}^{-}\right]\left[\mathrm{HCO}_{3}^{-}\right]-k_{2,1}\left[\mathrm{HCO}_{2} \mathrm{~S}^{-}\right]\left[\mathrm{R}_{3} \mathrm{~N}\right]+ \\
& k_{4,1}\left[\mathrm{OH}^{-}\right]\left[\mathrm{R}_{3} \mathrm{NH}^{+}\right]-k_{4,2}\left[\mathrm{R}_{3} \mathrm{~N}\right] \\
& \mathrm{R}_{3} \mathrm{NH}^{+} \quad R_{\mathrm{R}_{3} \mathrm{NH}}=k_{1,1}[\mathrm{COS}]\left[\mathrm{R}_{3} \mathrm{~N}\right]-k_{1,2}\left[\mathrm{HCO}_{2} \mathrm{~S}^{-}\left[\mathrm{pR}_{3} \mathrm{NH}^{+}\right]+\right. \\
& k_{2,2}\left[\mathrm{HCO}_{2} \mathrm{~S}^{-}\right]\left[\mathrm{R}_{3} \mathrm{~N}\right]-k_{2,2}\left[\mathrm{R}_{3} \mathrm{NH}^{+}\right]\left[\mathrm{HS}^{-}\right]\left[\mathrm{HCO}_{3}^{-}\right]+ \\
& k_{4,2}\left[\mathrm{R}_{3} \mathrm{~N}\right]-k_{4,1}\left[\mathrm{OH}^{-}\right]\left[\mathrm{R}_{3} \mathrm{NH}^{+}\right] \\
& \mathrm{OH}^{-} \quad R_{\mathrm{OH}}=k_{3,2}\left[\mathrm{CO}_{3}{ }^{2-}\right]-k_{3,1}\left[\mathrm{OH}^{-}\right]\left[\mathrm{HCO}_{3}{ }^{-}\right]+k_{4,2}\left[\mathrm{R}_{3} \mathrm{~N}\right]- \\
& k_{4,1}\left[\mathrm{OH}^{-}\right]\left[\mathrm{R}_{3} \mathrm{NH}^{+}\right] \\
& \mathrm{HS} \quad R_{\mathrm{HS}}=k_{2,1}\left[\mathrm{HCO}_{2} \mathrm{~S}^{-}\right]\left[\mathrm{R}_{3} \mathrm{~N}\right]-k_{2,2}\left[\mathrm{R}_{3} \mathrm{NH}^{+}\right]\left[\mathrm{HS}^{-}\right]\left[\mathrm{HCO}_{3}^{-}\right] \\
& \mathrm{HCO}_{2} \mathrm{~S}^{-} \quad R_{\mathrm{HCO}_{2} \mathrm{~S}}=k_{1,1}[\mathrm{COS}]\left[\mathrm{R}_{3} \mathrm{~N}\right]-k_{1,2}\left[\mathrm{HCO}_{2} \mathrm{~S}^{-}\right]\left[\mathrm{R}_{3} \mathrm{NH}^{+}\right]+ \\
& k_{2,2}\left[\mathrm{R}_{3} \mathrm{NH}^{+}\right]\left[\mathrm{HS}^{-}\right]\left[\mathrm{HCO}_{3}^{-}\right]-k_{2,1}\left[\mathrm{HCO}_{2} \mathrm{~S}^{-}\right]\left[\mathrm{R}_{3} \mathrm{~N}\right] \\
& \mathrm{HCO}_{3}{ }^{-} \quad R_{\mathrm{HCO}_{3}}=k_{2,1}\left[\mathrm{HCO}_{2} \mathrm{~S}^{-}\right]\left[\mathrm{R}_{3} \mathrm{~N}\right]-k_{2,2}\left[\mathrm{R}_{3} \mathrm{NH}^{+}\right]\left[\mathrm{HS}^{-}\right]\left[\mathrm{HCO}_{3}^{-}\right] \\
& +k_{3,2}\left[\mathrm{CO}_{3}^{2-}\right]-k_{3,1}\left[\mathrm{OH}^{-}\right]\left[\mathrm{HCO}_{3}{ }^{-}\right] \\
& \mathrm{CO}_{3}{ }^{2-} \quad R_{\mathrm{CO}_{3}}=k_{3,1}\left[\mathrm{OH}^{-}\right]\left[\mathrm{HCO}_{3}^{-}\right]-k_{3,2}\left[\mathrm{CO}_{3}{ }^{2-}\right]
\end{aligned}
$$

in Tables III and IV for DEMEA and MDEA, respectively. Although high-purity tertiary amines were used, additional care was taken to avoid any influence on the absorption flux of small amounts of rapidly reacting contaminants. Therefore a minimum amine conversion of at least $0.5 \%$ was applied in all absorption experiments. In order to evaluate the effect of the chemical reaction rate on the absorption rate, only absorption experiments in which at least some enhancement due to reaction occurred were taken into account. This requirement put a lower limit to the amine concentrations applied.

The experimentally observed absorption rates were compared to absorption rates calculated with the absorption model. Only independently determined data were applied as input data in these model simulations. The kinetic data used in the model calculations were those reported in part 1 of the present work (Littel et al., 1992b), which were determined from absorption experiments in an intensely stirred batch reactor. The calculated en- 
Table III. Experimental Results and Calculated Enhancement Factors for DEMEA $(T=303 \mathrm{~K})$

\begin{tabular}{|c|c|c|c|c|c|c|c|c|}
\hline $\begin{array}{c}\text { [DEMEA], } \\
\mathrm{mol} \mathrm{m}^{-3}\end{array}$ & $\begin{array}{l}{\left[\mathrm{H}_{2} \mathrm{O}\right]} \\
\mathrm{mol} \mathrm{m}^{-3}\end{array}$ & $\begin{array}{l}{[\mathrm{COS}]_{\mathrm{g}}} \\
\mathrm{mol} \mathrm{m}\end{array}$ & $\begin{array}{c}{[\mathrm{COS}]_{\mathrm{L}, \mathrm{tot}},} \\
\mathrm{mol} \mathrm{m}^{-3}\end{array}$ & $m_{\mathrm{COS}}$ & $\begin{array}{c}k_{\mathrm{L}, \mathrm{COS}} \\
10^{5} \mathrm{~m} \mathrm{~s}^{-1}\end{array}$ & $\begin{array}{c}D_{\mathrm{cos}} \\
10^{9} \mathrm{~m}^{2} \mathrm{~s}^{-1}\end{array}$ & $E_{\text {oxp }}$ & $E_{\text {calc }}$ \\
\hline 780 & 49973 & 6.6 & 21.8 & 0.435 & 1.55 & 1.34 & 1.375 & 1.246 \\
\hline 785 & 49939 & 4.1 & 23.7 & 0.435 & 1.60 & 1.34 & 1.325 & 1.232 \\
\hline 787 & 49927 & 7.0 & 20.2 & 0.435 & 1.44 & 1.33 & 1.352 & 1.284 \\
\hline 793 & 49888 & 11.4 & 11.8 & 0.435 & 1.43 & 1.33 & 1.414 & 1.300 \\
\hline 796 & 49867 & 11.5 & 11.0 & 0.434 & 1.52 & 1.33 & 1.368 & 1.271 \\
\hline 1168 & 47351 & 4.7 & 19.1 & 0.430 & 1.33 & 1.14 & 1.709 & 1.420 \\
\hline 1186 & 47231 & 7.0 & 21.3 & 0.430 & 1.19 & 1.13 & 1.874 & 1.509 \\
\hline 1188 & 47218 & 8.7 & 14.8 & 0.430 & 1.17 & 1.13 & 1.898 & 1.534 \\
\hline 1194 & 47178 & 7.7 & 15.0 & 0.430 & 1.17 & 1.13 & 1.824 & 1.536 \\
\hline 1197 & 47157 & 8.5 & 19.2 & 0.429 & 1.26 & 1.12 & 1.690 & 1.464 \\
\hline 1489 & 45186 & 16.1 & 25.9 & 0.428 & 1.06 & 0.99 & 2.045 & 1.673 \\
\hline 1489 & 45186 & 13.3 & 79.4 & 0.428 & 1.06 & 0.99 & 2.133 & 1.599 \\
\hline 1762 & 43346 & 4.5 & 24.2 & 0.429 & 1.02 & 0.89 & 2.257 & 1.759 \\
\hline 1778 & 43233 & 8.5 & 20.1 & 0.429 & 1.02 & 0.88 & 2.323 & 1.767 \\
\hline 1781 & 43213 & 5.2 & 22.6 & 0.429 & 1.17 & 0.88 & 2.082 & 1.609 \\
\hline 1782 & 43207 & 4.8 & 22.0 & 0.429 & 0.83 & 0.88 & 2.595 & 2.061 \\
\hline 2573 & 37864 & 6.1 & 19.4 & 0.440 & 0.64 & 0.65 & 4.183 & 2.655 \\
\hline 2574 & 37864 & 3.8 & 24.4 & 0.440 & 0.69 & 0.65 & 3.951 & 2.463 \\
\hline 2970 & 35188 & 12.4 & 45.1 & 0.450 & 0.62 & 0.56 & 4.618 & 2.672 \\
\hline 2970 & 35188 & 12.0 & 63.6 & 0.450 & 0.62 & 0.56 & 4.761 & 2.640 \\
\hline
\end{tabular}

Table IV. Experimental Results and Calculated Enhancement Factors for MDEA $(T=303 \mathrm{~K})$

\begin{tabular}{|c|c|c|c|c|c|c|c|c|}
\hline $\begin{array}{l}{[\mathrm{MDEA}]} \\
\mathrm{mol} \mathrm{m}^{-3}\end{array}$ & $\begin{array}{l}{\left[\mathrm{H}_{2} \mathrm{O}\right]} \\
\mathrm{mol} \mathrm{m}^{-3}\end{array}$ & $\begin{array}{l}{[\mathrm{COS}]_{\mathrm{g}},} \\
\mathrm{mol} \mathrm{m}\end{array}$ & $\begin{array}{l}{[\mathrm{COS}]_{\mathrm{L}, \text { tot, }}} \\
\mathrm{mol} \mathrm{m}\end{array}$ & $m_{\mathrm{Cos}}$ & $\begin{array}{c}k_{\mathrm{L}, \mathrm{COS}} \\
10^{5} \mathrm{~m} \mathrm{~s}^{-1}\end{array}$ & $\begin{array}{c}D_{\mathrm{cos}}, \\
10^{9} \mathrm{~m}^{2} \mathbf{s}^{-1} \\
\end{array}$ & $E_{\text {exp }}$ & $E_{\text {calc }}$ \\
\hline 1808 & 44420 & 7.9 & 16.8 & 0.408 & 0.99 & 0.97 & 1.392 & 1.186 \\
\hline 1801 & 44457 & 7.2 & 16.1 & 0.408 & 1.05 & 0.97 & 1.355 & 1.166 \\
\hline 1812 & 44394 & 8.2 & 17.5 & 0.408 & 1.00 & 0.96 & 1.317 & 1.183 \\
\hline 1818 & 44359 & 6.8 & 17.1 & 0.407 & 1.02 & 0.96 & 1.368 & 1.175 \\
\hline 2388 & 40923 & 7.8 & 17.7 & 0.387 & 0.80 & 0.75 & 1.773 & 1.303 \\
\hline 2377 & 40988 & 7.3 & 16.2 & 0.388 & 0.88 & 0.75 & 1.615 & 1.240 \\
\hline 2396 & 40873 & 6.6 & 16.8 & 0.387 & 0.75 & 0.75 & 1.783 & 1.318 \\
\hline 2408 & 40804 & 7.1 & 17.5 & 0.387 & 0.80 & 0.74 & 1.773 & 1.283 \\
\hline 3002 & 37218 & 7.8 & 17.7 & 0.361 & 0.57 & 0.57 & 2.558 & 1.490 \\
\hline 2994 & 37271 & 8.1 & 16.4 & 0.362 & 0.64 & 0.57 & 2.329 & 1.403 \\
\hline 3034 & 37025 & 7.1 & 16.2 & 0.360 & 0.50 & 0.56 & 2.881 & 1.605 \\
\hline 3025 & 37081 & 6.6 & 22.2 & 0.360 & 0.72 & 0.56 & 2.446 & 1.322 \\
\hline 3594 & 33652 & 10.0 & 13.1 & 0.331 & 0.46 & 0.43 & 3.328 & 1.655 \\
\hline 3588 & 33688 & 9.0 & 12.3 & 0.332 & 0.66 & 0.43 & 2.523 & 1.354 \\
\hline 3609 & 33561 & 10.5 & 14.3 & 0.332 & 0.45 & 0.43 & 3.445 & 1.674 \\
\hline
\end{tabular}

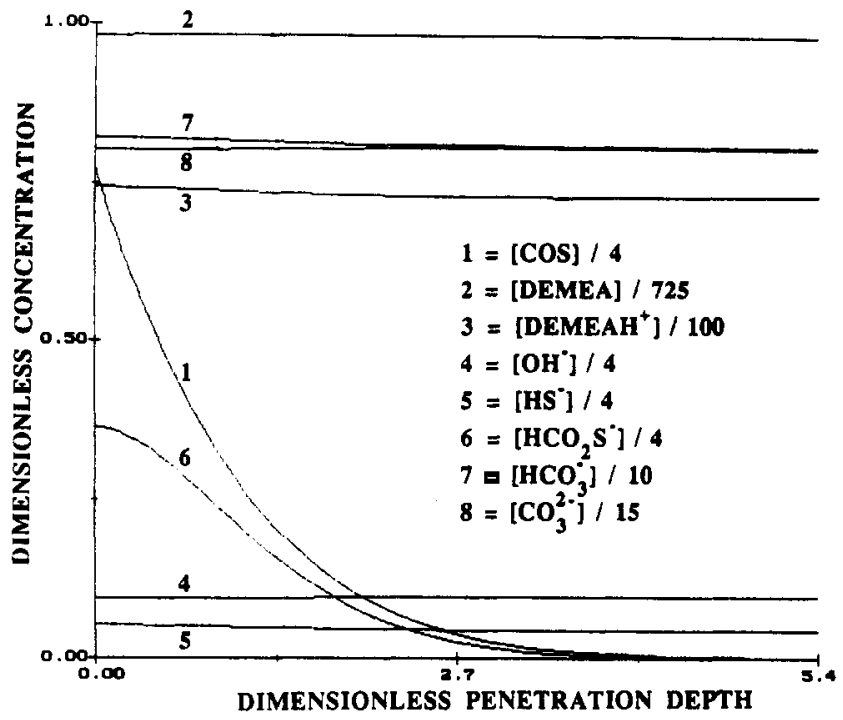

Figure 1. Typical concentration profile at the end of the contact time $\left(T=303 \mathrm{~K},[D E M E A]=787 \mathrm{~mol} \mathrm{~m}^{-3},[\mathrm{COS}]_{\mathrm{g}}=7.0 \mathrm{~mol} \mathrm{~m}^{-3}\right.$, $\left.[\mathrm{COS}]_{\mathrm{L}, \text { tot }}=20.2 \mathrm{~mol} \mathrm{~m}-k_{\mathrm{L}, \cos }=1.44 \times 10^{-5} \mathrm{~m} \mathrm{~s}^{-1}\right)$.

hancement factors are presented in Tables III and IV for DEMEA and MDEA, respectively. A typical concentration profile calculated with the absorption model is presented in Figure 1.

For DEMEA, comparison of experimental and calculated enhancement factors shows that the agreement be-

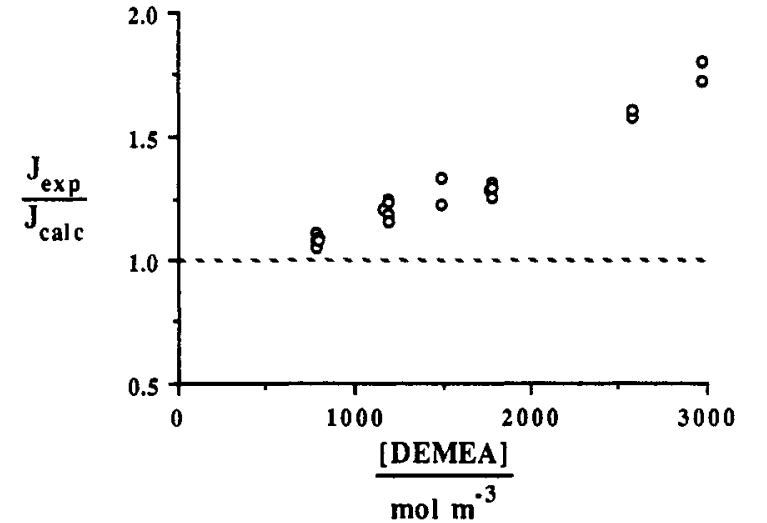

Figure 2. Experimental and calculated absorption fluxes for DEMEA.

tween experiment and simulation is acceptable at low amine concentrations. However, a considerable difference exists at high amine concentrations and the difference between experiment and simulation increases with increasing amine concentration. These observations are illustrated by Figure 2, which shows the ratio between experimental and calculated absorption flux as a function of the amine concentration. The same observations hold for the kinetic experiments with aqueous MDEA solutions as is shown by Figure 3. Tables III and IV and Figures 2 and 3 show a good reproducibility of the experimental data. 


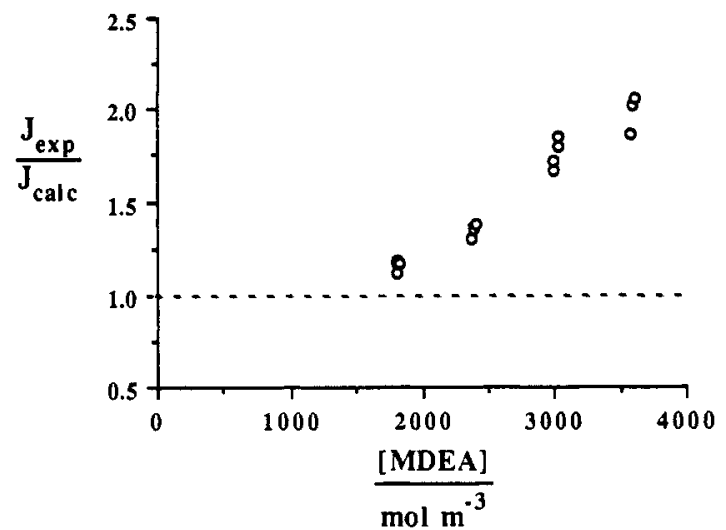

Figure 3. Experimental and calculated absorption fluxes for MDEA.

All model calculations and experiments showed enhancement of the physical absorption rate due to chemical reaction as is illustrated by the enhancement factors presented in Tables III and IV. At the lower amine concentrations, however, these enhancement factors are only slightly higher than 1 , which indicates that the absorption rate is only partially determined by the chemical reaction. Therefore the calculated absorption rates are not very sensitive to the exact values for the chemical reaction rate constants.

In judging the observed differences between experiment and model calculation, the reliability and influence on the calculated absorption flux of the various input data and assumptions underlying the model calculations should be considered. Extensive model simulations showed that the forward reaction rate of the first step of the proposed reaction mechanism for $\mathrm{COS}$ with tertiary amines (reaction 1 ) is entirely rate determining under the conditions and amine concentrations applied in the stirred cell experiments. Particularly the forward reaction rate constant of the first step of reaction 1 could be determined accurately with the experimental technique described in part 1 (Littel et al., 1992b). Since the forward reaction rate of reaction 1 is entirely rate determining, the influence of the equilibrium constants $K_{\mathrm{COS} 1}$ and $K_{\mathrm{COS} 2}$ (see Table I) on the calculated absorption flux is negligible and the uncertainty in the exact value of these equilibrium constants is not important. Hence, the observed differences between experiment and calculation do not stem from flaws in kinetic or equilibria data.

Diffusivity and solubility are physical input data which have a definite influence on the calculated absorption rate. The estimation method of the COS diffusivity in aqueous amine solutions seems to be susceptible to minor inaccuracies. However, the absorption rate is proportional to $D^{1 / 2}$ and the observed differences between experimental and calculated absorption rates at high amine concentrations would result from an (unreasonable) underestimation of the COS diffusivity of more than a factor of 4 .

The COS solubility in aqueous amine solutions is estimated by means of a COS- $\mathrm{N}_{2} \mathrm{O}$ analogy. Physical absorption experiments in aqueous solutions of ethylene glycol and sulfolane suggested that this analogy is only valid for relatively diluted aqueous solutions and tends to underestimate the COS solubility considerably at higher concentrations (Littel et al., 1992a). This was confirmed by kinetic experiments of $\mathrm{COS}$ in aqueous solutions of primary and secondary amines (Littel et al., 1992c). In the present work rather high amine concentrations were applied because the low forward reaction rate constant of reaction 1 put a lower limit to the amine concentration. The observed absorption rate is proportional to the COS

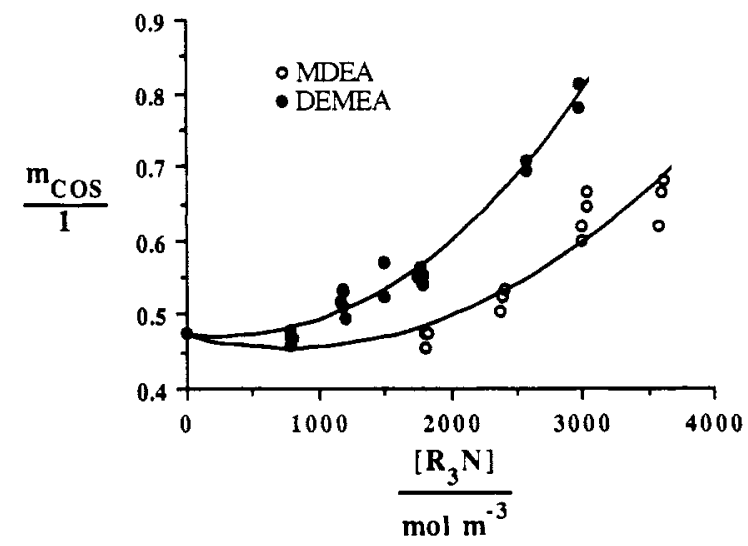

Figure 4. Calculated COS solubilities for MDEA and DEMEA.

solubility, and the differences between experimental and calculated absorption rates would result from an underestimation of the COS solubility of about a factor of 2 at the highest amine concentrations applied. The underestimation of the COS solubility in rather concentrated amine solutions seems a very reasonable explanation for the differences between experimental and calculated absorption rates and the trend in these differences as shown in Figures 2 and 3.

The absorption model can also be used to estimate COS solubilities from the present absorption experiments. The calculated COS solubilities have been plotted in Figure 4 as a function of the amine concentration. The solubilities are shown, at first, to decrease slightly with increasing amine concentration, and subsequently they increase substantially with a further increase of the amine concentration. This general pattern is for DEMEA stronger than for MDEA. The same general pattern has been reported for the $\mathrm{N}_{2} \mathrm{O}$ solubility in aqueous amine solutions, although the minimum in the solubility is usually observed at rather high amine concentrations (see, e.g., Versteeg and Oyevaar, 1989). For aqueous DEMEA solutions at $333 \mathrm{~K}$ this minimum in the $\mathrm{N}_{2} \mathrm{O}$ solubility is already observed at about $0.5 \mathrm{M}$ (Littel et al., 1992a).

4.2. Discussion of Work of Al-Ghawas et al. (1989). Recently Al-Ghawas et al. (1989) presented kinetic data for the reaction between COS and aqueous MDEA solutions at temperatures ranging from 293 to $313 \mathrm{~K}$. All their kinetic experiments were carried out in a wetted sphere absorber which is a continuously operated model reactor characterized, in general, by higher specific mass-transfer rates than the stirred cell reactor. Al-Ghawas et al. (1989) reported that the observed absorption rates were considerably enhanced by chemical reaction. They observed that the chemical reaction rate was first order in both amine and $\operatorname{COS}$ concentration and proposed a reaction mechanism which is identical to the first step (reaction 1) of the reaction mechanism proposed in part 1 (Littel et al., 1992b). The reaction rates reported by Al-Ghawas et al. (1989) were considerably higher than those observed in the present work. They found no evidence for the occurrence of the hydrolysis of $\mathrm{COS}$ toward $\mathrm{H}_{2} \mathrm{~S}$ and $\mathrm{CO}_{2}$. Al-Ghawas and Sandall (1991) applied the kinetic data reported by Al-Ghawas et al. (1989) to describe experiments for the simultaneous absorption of $\mathrm{H}_{2} \mathrm{~S}, \mathrm{COS}$, and $\mathrm{CO}_{2}$ into aqueous MDEA solutions. The sensitivity of these absorption experiments toward the reaction rates of $\operatorname{COS}$ was only very minor, and consequently, these experiments cannot be seen as a confirmation of the kinetic data presented by Al-Ghawas et al. (1989).

The penetration theory absorption model developed in the present work was applied to investigate the discrep- 
Table V. Simulation Results for the Data Presented by Al-Ghawas et al. (1989)

\begin{tabular}{|c|c|c|c|c|c|c|c|c|}
\hline$T, \mathrm{~K}$ & $\begin{array}{l}\text { [MDEA], } \\
\mathrm{mol} \mathrm{m}^{-3}\end{array}$ & $\begin{array}{l}{\left[\mathrm{H}_{2} \mathrm{O}\right]} \\
\mathrm{mol} \mathrm{m}^{-3}\end{array}$ & $\begin{array}{l}{[\mathrm{COS}]_{\text {g,int, }}} \\
\mathrm{mol} \mathrm{m}^{-3}\end{array}$ & $\begin{array}{l}{[\mathrm{COS}]_{\mathrm{L}, \mathrm{tot}},} \\
\mathrm{mol} \mathrm{m}^{-3}\end{array}$ & $\begin{array}{c}k_{\mathrm{L}, \mathrm{COS}} \\
10^{5} \mathrm{~m} \mathrm{~s}^{-1}\end{array}$ & $\begin{array}{c}J_{\mathrm{Cos}}, \\
10^{3} \mathrm{~mol} \mathrm{~m}^{-2} \mathrm{~s}^{-1} \\
\end{array}$ & $E_{\exp }$ & $E_{\text {calc }}$ \\
\hline 293 & 1259 & 47200 & 23.28 & 0 & 4.44 & 1.47 & 1.417 & 1.007 \\
\hline 298 & & & 20.26 & 0 & 4.85 & 1.43 & 1.455 & 1.006 \\
\hline 303 & & & 17.65 & 0 & 5.37 & 1.43 & 1.504 & 1.000 \\
\hline 308 & & & 15.38 & 0 & 5.80 & 1.37 & 1.534 & 1.006 \\
\hline 313 & & & 13.39 & 0 & 6.28 & 1.34 & 1.593 & 1.008 \\
\hline 293 & 1714 & 44200 & 22.45 & 0 & 3.78 & 1.35 & 1.591 & 1.004 \\
\hline 298 & & & 19.63 & 0 & 4.19 & 1.36 & 1.652 & 1.011 \\
\hline 303 & & & 17.17 & 0 & 4.62 & 1.36 & 1.708 & 1.006 \\
\hline 308 & & & 15.01 & 0 & 5.06 & 1.32 & 1.733 & 1.013 \\
\hline 313 & & & 13.10 & 0 & 5.50 & 1.32 & 1.837 & 1.016 \\
\hline 293 & 2599 & 38400 & 20.68 & 0 & 2.63 & 1.09 & 2.007 & 1.015 \\
\hline 298 & & & 18.31 & 0 & 3.03 & 1.16 & 2.085 & 1.020 \\
\hline 303 & & & 16.17 & 0 & 3.32 & 1.20 & 2.246 & 1.018 \\
\hline 308 & & & 14.24 & 0 & 3.78 & 1.22 & 2.268 & 1.031 \\
\hline 313 & & & 12.50 & 0 & 4.14 & 1.30 & 2.509 & 1.039 \\
\hline
\end{tabular}

ancies between the present experimental data and the kinetic data reported by Al-Ghawas et al. (1989). Model calculations were carried out for all data presented by Al-Ghawas et al. (1989) applying the kinetic rate constants obtained in part 1 of the present work and the physical data provided by Al-Ghawas et al. (1989). The total concentration COS in the bulk of the liquid which flows through the reactor is zero, because Al-Ghawas et al. (1989) report the use of freshly made solutions for each experiment. A survey of the input data used in the model simulations is presented in Table V together with the calculated enhancement factors.

For all experiments reported by Al-Ghawas et al. (1989) enhancement factors equal to 1 were calculated with the model of the present study, which expresses that the absorption rate is entirely determined by physical absorption. Hence, the enhancement factors observed by Al-Ghawas et al. (1989) cannot be explained by the kinetic data for MDEA determined in part 1 of the present study. A possible explanation for this discrepancy may be the presence of small amounts of rapidly reacting primary and secondary amines in the tertiary amine solutions applied by Al-Ghawas et al. (1989). Especially at very low amine conversions, as encountered in the wetted sphere absorber, the absorption rate can be affected considerably by small amounts of contaminants as has been shown for $\mathrm{CO}_{2}$ absorption rates into tertiary amine solutions by Versteeg and van Swaaij (1988a).

The present model offers the option to describe the absorption of COS in a mixture of a tertiary amine and a primary or secondary amine. Calculations were carried out assuming the presence of small amounts of the secondary amine methylmonoethanolamine (MMEA). The reaction between COS and aqueous solutions of MMEA has been investigated by Littel et al. (1992c). The reaction mechanism was found to be a zwitterion mechanism, and the overall reaction rate was entirely determined by the deprotonation of the zwitterion. In this zwitterion deprotonation all bases present in solution will take part and the overall reaction rate between COS and MMEA will increase considerably if large amounts of tertiary amine are present (see also Littel et al., 1992d). This interaction between MMEA and MDEA has not been taken into account, however, in the present model calculations. In Figure 5 the calculated absorption rate for a MMEA/ MDEA mixture is plotted as a function of the MMEA concentration for one of the kinetic experiments reported by Al-Ghawas et al. (1989). This figure clearly shows the large effect of relatively small amounts MMEA on the absorption rate. If the underestimation of the COS solubility, which follows from Figure 4, is taken into account, the absorption rate observed by Al-Ghawas et al. (1989)

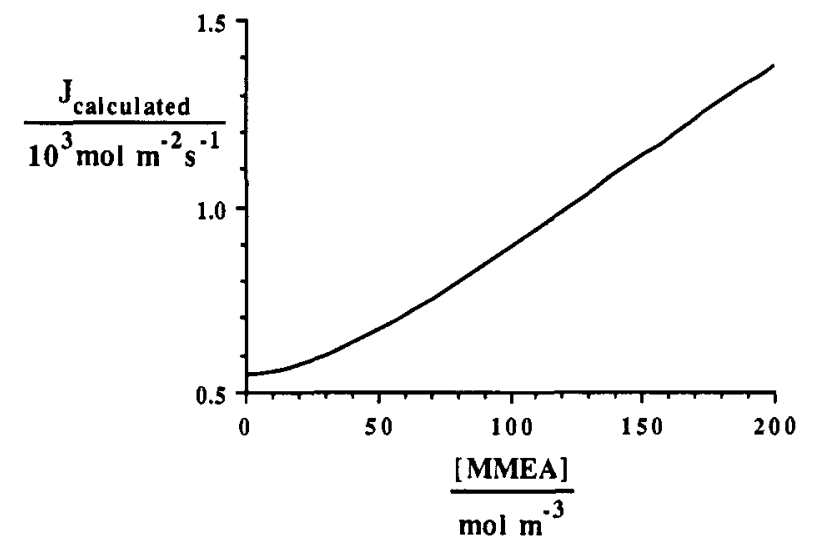

Figure 5. Calculated absorption fluxes for mixtures of MMEA and $\operatorname{MDEA}\left(T=303 \mathrm{~K},[\mathrm{MDEA}]+[\mathrm{MMEA}]=2599 \mathrm{~mol} \mathrm{~m}^{-3},[\mathrm{COS}]_{\text {qint }}\right.$ $\left.=16.2 \mathrm{~mol} \mathrm{~m}^{-3},[\mathrm{COS}]_{\mathrm{L}, \text { tot }}=0 \mathrm{~mol} \mathrm{~m}^{-3}, k_{\mathrm{L}, \mathrm{COS}}=3.32 \times 10^{-5} \mathrm{~m} \mathrm{~s}^{-1}\right)$.

could be explained by a MMEA concentration of about 80 mol m $\mathrm{m}^{-3}$ (i.e., $3 \mathrm{~mol} \%$ ). This seems a rather large contamination. However, it should be considered that the interaction between MMEA and MDEA, which is likely to increase the reaction rate of COS with MMEA substantially, has not been taken into account. The presence of small amounts of contaminants might also explain the absence of COS hydrolysis products $\left(\mathrm{H}_{2} \mathrm{~S}, \mathrm{CO}_{2}\right)$ reported by Al-Ghawas et al. (1989) because stable thiocarbamates can be formed between COS and primary or secondary amines.

\section{Conclusions}

Absorption experiments of COS into aqueous solutions of MDEA and DEMEA have been carried out in a stirred cell reactor at $303 \mathrm{~K}$. The experiments were interpreted by means of a numerically solved absorption model using the kinetic data obtained in part 1 of the present work (Littel et al., 1992b).

Experimental and calculated absorption rates agreed reasonably well at relatively low amine concentrations but deviated increasingly with increasing amine concentration. It has been argued that these deviations very probably must be attributed to an underestimation of the COS solubility in rather concentrated amine solutions. The observation that the COS $-\mathrm{N}_{2} \mathrm{O}$ analogy is only valid for relatively diluted aqueous solutions is in agreement with other work (Littel et al., 1992a,c).

The absorption model has been applied to investigate the discrepancies between the present work and the kinetic data reported by Al-Ghawas et al. (1989). It has been shown that the absorption rates measured by Al-Ghawas et al. (1989) were possibly affected considerably by small amounts of rapidly reacting contaminants. 


\section{Acknowledgment}

These investigations were supported by the Koninklijke/Shell Laboratorium, Amsterdam, The Netherlands. We also acknowledge W. Leppink for the construction of the experimental setup and C. van der Beek, W. Lengton, and $\mathrm{G}$. Oudendijk for their part in the experimental work.

\section{Nomenclature}

$C=$ concentration, $\mathrm{mol} \mathrm{m} \mathrm{m}^{-3}$

$D=$ diffusivity, $\mathrm{m}^{2} \mathrm{~s}^{-1}$

$E=$ enhancement factor

$J=$ mole flux, mol m $\mathrm{m}^{-2} \mathrm{~s}^{-1}$

$k_{\mathrm{g}}=$ gas-phase mass-transfer coefficient, $\mathrm{m} \mathrm{s}^{-1}$

$k_{\mathrm{L}}=$ liquid-phase mass-transfer coefficient, $\mathrm{m} \mathrm{s}^{-1}$

$m=$ dimensionless solubility

$t=$ time variable, $\mathrm{s}$

$T=$ temperature, $\mathrm{K}$

$x=$ space variable, $\mathrm{m}$

Subscripts/Superscripts

bulk $=$ bulk conditions

calc $=$ calculated

$\exp =$ experimental

$i=$ component $i$

int $=$ interfacial

$\mathrm{g}=$ gas phase

$\mathrm{L}=$ liquid phase

tot $=$ total (i.e., free and converted)

Amine Abbreviations

DEMEA = diethylmonoethanolamine

MDEA $=N$-methyldiethanolamine

MMEA = methylmonoethanolamine

$\mathrm{R}_{3} \mathrm{~N}=$ tertiary amine

Registry No. MDEA, 105-59-9; DEMEA, 100-37-8; COS, 463-58-1.

\section{Literature Cited}

Al-Ghawas, H. A.; Sandall, O. C. Simultaneous absorption of carbon dioxide, carbonyl sulfide and hydrogen sulfide in aqueous methyldiethanolamine. Chem. Eng. Sci. 1991, 46, 665-676.
Al-Ghawas, H. A.; Ruiz-Ibanez, G.; Sandall, O. C. Absorption of carbonyl sulfide in aqueous methyldiethanolamine. Chem. Eng. Sci. 1989, 44, 631-639.

Blauwhoff, P. M. M.; Versteeg, G. F.; van Swaaij, W. P. M. A study on the reaction between $\mathrm{CO}_{2}$ and alkanolamines in aqueous solutions. Chem. Eng. Sci. 1984, 39, 207-225.

Cornelisse, R.; Beenackers, A. A. C. M.; van Beckum, F. P. H.; van Swarij, W. P. M. Numerical calculation of simultaneous mass transfer of two gases accompanied by complex reversible reactions. Chem. Eng. Sci. 1980, 35, 1245-1260.

Littel, R. J.; Filmer, B.; Versteeg, G. F.; van Swaaij, W. P. M. Modelling of simultaneous absorption of $\mathrm{H}_{2} \mathrm{~S}$ and $\mathrm{CO}_{2}$ in alkanolamine solutions: The influence of parallel and consecutive reversible reactions and the coupled diffusion of ionic species. Chem. Eng. Sci. 1991, 46, 2303-2313.

Littel, R. J.; Versteeg, G. F.; van Swaaij, W. P. M. Solubility and diffusivity data for the absorption of $\mathrm{COS}, \mathrm{CO}_{2}$, and $\mathrm{N}_{2} \mathrm{O}$ in amine solutions. J. Chem. Eng. Data 1992a, 37, 49-55.

Littel, R. J.; Versteeg, G. F.; van Swaaij, W. P. M. Kinetic study of COS with tertiary alkanolamine solutions. 1 . Experiments in an intensely stirred batch reactor. Ind. Eng. Chem. Res. 1992b, preceding paper in this issue.

Littel, R. J.; Versteeg, G. F.; van Swaaij, W. P. M. On the kinetics of $\mathrm{COS}$ with primary and secondary amines in aqueous solutions. $A I C h E J .1992 c$, in press.

Littel, R. J.; Versteeg, G. F.; van Swaaij, W. P. M. Kinetics of $\mathrm{CO}_{2}$ with primary and secondary amines in aqueous solutions-I: Zwitterion deprotonation kinetics for DEA and DIPA in aqueous blends of alkanolamines. Chem. Eng. Sci. 1992d, in press.

Philipp, B.; Dautzenberg, H. Kinetische Untersuchungen zur Bildung und Zetsetzung von Monothiocarbonat in wässrige Lösung. Z. Phys. Chem. 1965, 229, 210-224.

Versteeg, G. F.; van Swaaij, W. P. M. On the kinetics between $\mathrm{CO}_{2}$ and alkanolamines both in aqueous and non-aqueous solutionsII: Tertiary amines. Chem. Eng. Sci. 1988a, 43, 587-591.

Versteeg, G. F.; van Swaaij, W. P. M. Solubility and diffusivity of acid gases $\left(\mathrm{CO}_{2}, \mathrm{~N}_{2} \mathrm{O}\right)$ in aqueous alkanolamine solutions. $J$. Chem. Eng. Data 1988b, 33, 29-34.

Versteeg, G. F.; Oyevaar, M. H. The reaction between $\mathrm{CO}_{2}$ and diethanolamine at 298 K. Chem. Eng. Sci. 1989, 44, 1264-1268.

Versteeg, G. F.; Kuipers, J. A. M.; van Beckum, F. P. H.; van Swaaij, W. P. M. Mass transfer with complex reversible chemical reactions-I: Single reversible chemical reactions. Chem. Eng. Sci. 1989, 44, 2295-2310.

Received for review July 25, 1991 Revised manuscript received January 30, 1992 Accepted February 5, 1992

\title{
Steam Gasification of Lignocellulosic Residues in a Fluidized Bed at a Small Pilot Scale. Effect of the Type of Feedstock
}

\author{
Javier Herguido, Josê Corella,* and José González-Saiz \\ Chemical and Environmental Engineering Department, University of Zaragoza, 50009 Zaragoza, Spain
}

Different biomass materials such as pine sawdust, pine wood chips, cereal straw, and thistles (Cynara cardunculus) from energetic crops have been gasified with steam in a $15-\mathrm{cm}$-i.d. fluidized bed reactor. The gas, tar, and char yields, the composition and heating value of the gas produced, and the conversion of carbon have been determined at temperatures between 650 and $780^{\circ} \mathrm{C}(923-1053 \mathrm{~K})$ for each material. The product distribution varies with the biomass used and the gasification temperature. The differences are very marked for the $\mathrm{H}_{2}, \mathrm{CO}$, and $\mathrm{CO}_{2}$ contents in the gas product at low gasification temperatures. These differences decrease when the temperature increases to 780 ${ }^{\circ} \mathrm{C}$ at which point a gas composition similar for all types of biomass tested is obtained by the achievement of equilibrium in the water-gas shift reaction.

\section{Introduction}

The gasification of biomass, lignocellulosic residues, refuse derived fuel (RDF), organic wastes, etc., is a thermochemical process for destruction of such solids with simultaneous production of a valuable gas. Today it seems to be not economically competitive, and research on it has ceased in some laboratories. Nevertheless in some scenarios it could be attractive. The state of the art and its 